\title{
The influence of demographic factors on the supply of company training places in Germany
}

Tobias Maier $^{1 *}$ and Günter Walden ${ }^{2}$

\author{
* Correspondence: \\ tobias.maier@bibb.de \\ 'Division "Qualifications, \\ Occupational Integration and \\ Employment", Federal Institute for \\ Vocational Education and Training, \\ Robert-Schuman-Platz 3, 53175 \\ Bonn, Germany \\ Full list of author information is \\ available at the end of the article
}

\begin{abstract}
Background: In the German dual system of vocational education and training, the question arises of whether and how enterprises react to demographic changes by adjusting their supply of training places.

Methods: We conduct a time series on Western German data from 1970 to 2011 and construct a panel data set from 1977 to 2011 based on data of the West German states ("Bundesländer") to estimate the influence of demographic changes over time.

Results: We can show that demographic factors strongly influenced the Federal Republic prior to 1990. After the reunification, a positive influence of demographic factors is still observed but only for young people with higher levels of education; in large part, factors related to economic growth and the job market dominate.

Conclusions: Our findings suggest that, compared to prior times, policy makers nowadays only have limited abilities to influence the number of training places offered by companies through appeals to community spirit. Instead, strategies of gaining additional training places should be geared towards the economic interests of enterprises.
\end{abstract}

Keywords: Vocational training; Firm employment decisions; Labour demand; Model construction and estimation

\section{Background}

In the German dual system of vocational education and training (VET) - a combination of learning in the enterprise and in a vocational school - the enterprises determine the number of training places and recruit trainees. The public judges how well the system functions by the extent to which the companies provide a sufficient number of apprenticeships for each rising generation (Walden and Troltsch 2011). Thus, the assessment of the training market, and in particular the question of how many applicants to a training place did not end up in the dual system, plays a major role both in vocational training policy (e.g., Bundesinstitut für Berufsbildung 2011) and in research (e.g., Baethge et al. 2007). Due to its great importance for both social and education policy, the question arises of how sensitively firms react to changes in demographic trends and in the demand for apprenticeships by providing the appropriate education and training opportunities.

\section{Initial theoretical reflections}

Economic approaches to education in the tradition of human capital theory (Becker 1995) are geared towards explaining why enterprises participate in training by 
contrasting the costs and returns for the enterprises. The companies favour training whenever returns exceed costs and decide against it otherwise. Based on Becker's distinction between general and specific human capital, an intensive discussion has unfolded in economic circles regarding the conditions under which enterprises invest in human capital and/or do their own training.

Further developments in economic theory proceed from the more realistic assumption of imperfect job markets and show that the economic reasons behind company investments in general human capital can be inferred even under imperfect conditions. Wolter and Ryan (2011) give a detailed overview of the current state of the scientific discussion. In particular, a distinction can be drawn between two basic models of the motivation behind company training activities. In the so-called production model of training (Lindley 1975), the trainees finance their training by means of parallel productive work. In the so-called investment model of training (Merrilees 1983) the costs of providing training exceed the returns during the training period, and the enterprises depend on longer-term returns that accrue only after the completion of the training phase.

Irrespective of whether the production or the investment model of training predominates, company training activities seem to be connected largely with the fundamental framework conditions in an enterprise and, more specifically, with the economic situation, employment trends and demand for skilled workers (Troltsch and Walden 2010). The influence of supply-related factors is therefore plausible, according to this theoretical approach. To what extent, however, can the dependence on demand and on demographic developments be justified? If the enterprises base their supply of training places on their own economic interests, the possibility of reacting to demographic changes with training offers can occur only in two different ways: either, if it were not previously possible to meet the needs of the enterprises (ceteris paribus (c.p.)). Thus offering an expansion of the number of training places would then make it possible for the enterprises to fill places that were previously vacant. Or if demographic change would be accompanied by decreasing training costs (c.p.) leading to a higher attractiveness of training for companies.

In the past, however, the demand for apprenticeships always has exceeded the number of places offered (Kau et al. 2010, p. 70) and training costs were rather stable until 2000 (Schönfeld et al. 2010). It should be noted here that enterprises do not consider all young applicants suitable. It can be assumed that the companies formulate minimum requirements for potential trainees, and only those young people are accepted who are considered by the enterprises to meet those requirements. Empirical relationships between the number of training places offered and the demographics should therefore be stronger for school graduates with higher levels of education. Results deviating from this expectation could not be explained by economic factors alone.

Busemeyer (2009, pp. $106 \mathrm{ff}$.) sees an empirical indication that - apart from a pure costbenefit ratio - business also has responded to claims by politics and society regarding VET. He characterises the development of the VET system in the eighties as a sort of dual strategy. On the one hand, dismantling regulations and bureaucracy while containing the education and reform euphoria of the seventies; on the other hand, appealing to business to fulfil its responsibility to society. The increase in the number of apprenticeships offered in the 1980s, the argument goes, indicates that business has reacted flexibly and promptly to changes in demand in accepting social responsibility for young people. 


\section{State of research}

The relationship between changes in the demand for training places and/or demographics and the number of apprenticeships offered has so far been subject to only rudimentary scientific examination (for a bibliography, see Brunello 2009). This is surprising, because in public discussions about the supply of training places for young people, the enterprises are aware of pertinent expectations. The limited existing empirical research certainly suggests connections between the supply of and the demand for company training, however. In a comparative analysis of supply and demand trends, Troltsch and Walden (2007) conclude that the connection between supply and demand must have been more pronounced in the past than today. For the period since 2000 in particular, they postulate a weaker connection between supply and demand and greater emphasis on economic interests and/or on need criteria by the enterprises.

Using an econometric forecast model, Kau and Lösch (2005) attempt to estimate the influence of different factor complexes on the training activity during the period 1970-2003. Using a principal component analysis, they determine that demographic factors explain $61 \%$ of the variation in training activity, which would indicate a strong connection between supply and demand during the entire period. However, this cannot necessarily be interpreted as causation. Moreover, it is not clear to what extent the demographic and economic influence changes over time. Thus, to this date, no analysis over a longer time period has clearly defined the relevant demographic factors and hypotheses. That is to be carried out in this article using a time series analysis of the past 42 years and a panel analysis of the last 35 years.

\section{Description}

Figure 1 shows the numbers of persons graduating from schools of general education since 1970, the number of newly signed training contracts as of 30 September each year and the overall supply of apprenticeship places ("newly signed training contracts" + "vacant apprenticeship training positions"). If one looks at the total number of graduates from 1970 to the early 1990s, one can discern a bell-shaped curve with its peak at the beginning of the 1980s. After 1985, we see a nearly linear decrease until the beginning of the 1990s. The number of lower secondary school graduates has decreased since the end of the 1970s, while the number of pupils with leaving certificates from intermediate secondary school or intermediate general school is similar to that of graduates from schools of general education. The number of newly signed training contracts before 1991 follows the trend exhibited by graduates from schools of general education, with the largest number of new contracts signed in 1985. In the early 1970s and from 1985 to 1995 many apprenticeship training positions could not be filled. However, except for the year 1991, the number of school graduates has always been higher than the supply of apprenticeship places. ${ }^{\text {a }}$

After German reunification, however, the number of new contracts in West Germany has hovered just under 460,000 per year. Unlike in the case of increasing numbers of graduates from schools of general education, no trend is visible here. In the following, we will therefore examine whether any demand-induced changes in the number of trainees hired by companies have occurred in the past 42 years. 


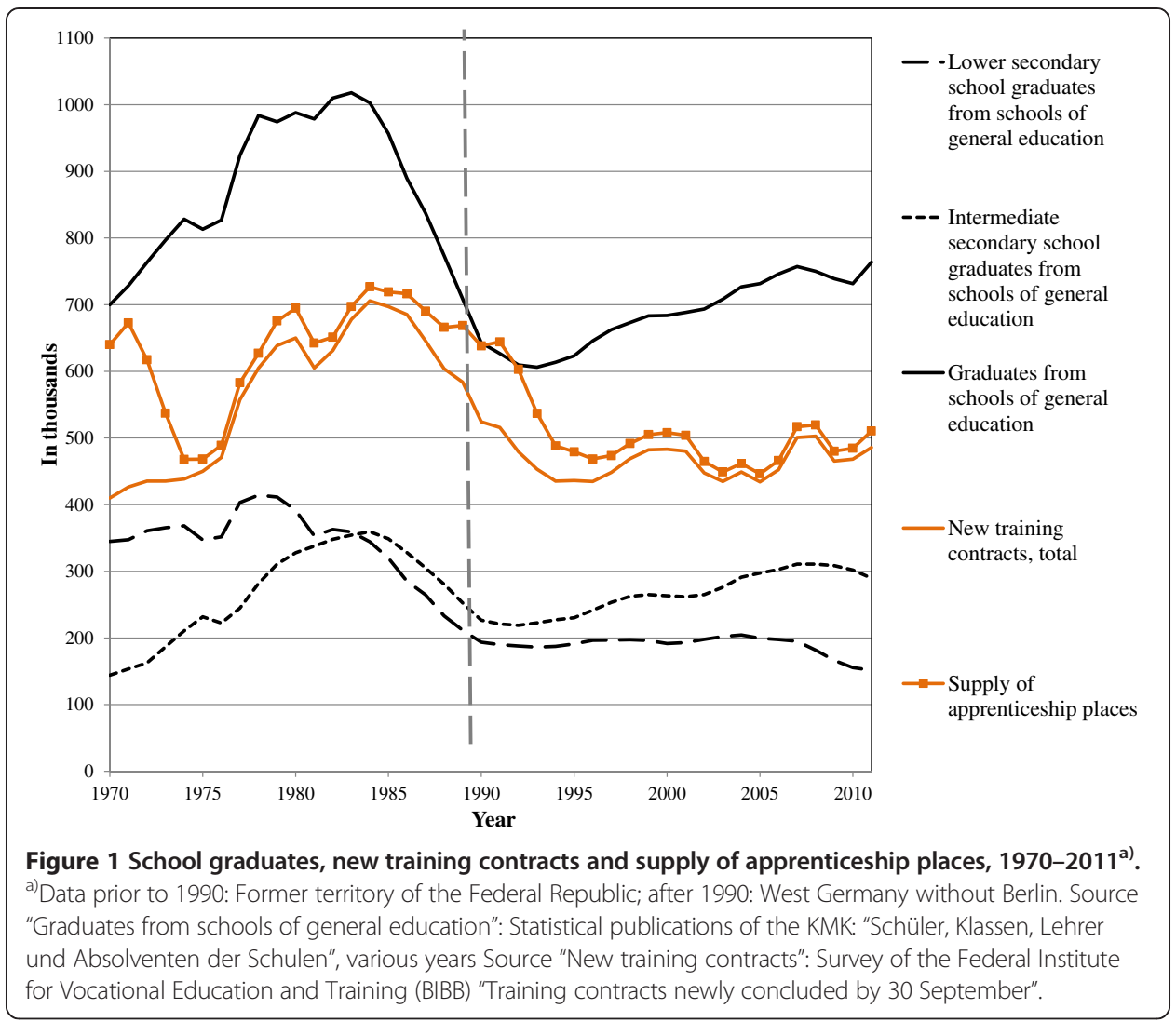

\section{Methods}

\section{Hypotheses and analysis model}

Using time series and panel analyses, we ask to what extent the supply of training places reacts to demographic changes. On the one hand, we will consider the supply of apprenticeship places ("newly signed training contracts" + "vacant apprenticeship training positions"), on the other hand, we will also take the number of new contracts into account as they can reflect the actual willingness of enterprises to invest in VET. Besides demographic variables relevant economic variables are taken into account. In the model, a distinction will be made between young people considered by the companies to be more suitable for training and those that the companies consider less suitable.

If one designates the number of supplied training places as $S$, the demand of young people who meet the minimum requirements as $D M$, the demand of young people who do not meet the minimum requirements as $D N$ and other influencing factors as $Z$ (e.g. training costs), the following initial interrelationship emerges, whereby $\Delta$ designates the change in each case:

$$
\Delta S=a+b_{1} * \Delta D M+b_{2} * \Delta D N+b_{3} * \Delta Z+e
$$

For the starting situation, we assume $D>S(D M+D N=D)$ for the whole observation period in accordance with existing empirical observations (Kau et al. 2010, p. 70). Because we cannot make assumptions about the relationship between the total supply and the demand of young people who meet the minimum requirements, $b_{1}$ is, in this case, initially indefinite and depends on the previous relationship between the total 
supply and demand of young people who meet the minimum requirements. $b_{2}$ should always be zero, however. That means, an increase in the number of apprentices who do not meet the minimum requirements of companies would not affect the supply of training places.

\section{Empirical models}

We will test this initial reflection for different time periods in Germany's history. Therefore, we first conduct a time-series analysis (OLS- regression) based on macro data of the western part of the Federal Republic of Germany (excluding Berlin) for the years from 1970 to 2011. As a Quandt-Andrews and also a Chow breakpoint test confirm our theoretical reflection that recruitment behaviour of German enterprises changed after the German reunification, we compare the pre-unification period (1970-1990) with the post-unification period (1991-2011) by multiplying the according explanatory variables with two dummy variables for the two periods. This is the same as conducting two separate time series regressions for the specified periods. Due to the limited number of cases, we use a factor analysis with orthogonal rotation to bundle the information of the economy and the labour market into two variables GROWTH and LABOUR MARKET. The coefficients of the time series analysis are comparable between the pre- and post-unification period because in each period we have the same amount of time points (21) and all variables are standardised and are measured in growth rates. A more detailed description of the data and the method can be found in the results section "Data, variables and influencing factors" of the time-series analyses.

In the second part of our analysis, we construct a panel data set from 1977 to 2011, based on data of the West German states ("Bundesländer") excluding Berlin (see the results section "Data, variables and influencing factors" of the panel-data analyses) to analyse the effects of the different independent variables in different time periods on the supply of apprenticeship places in further detail. To consider regional dependencies between the states, we cluster the states in the north (Bremen, Hamburg, Lower Saxony, Schleswig-Holstein) and south west (Hesse, Rhineland-Palatinate and Saarland) as two regions. To visualise the different effects of the independent variables in the different time periods, we estimate a fixed effects panel regression for the first 15 time points (e.g. 1977 to 1990) and then we repeat the estimation for the next 15 time points (e.g. 1978 to 1991) and so on. Then we compare the effects of the different 22 rolling fixed effects panel regressions with cluster robust standard errors (from 1977 to 1990 until 1997 to 2011). For straightforward interpretation of the coefficients, all variables are included in the regression in logarithmic form. All variables are macro variables and publicly accessible from the indicated sources (see Tables and Figures). However, they can also be requested from the authors.

\section{Results}

Time-series analyses for 1970-2011

Data, variables and influencing factors

To test equation (1) we use the growth rate of the annually supplied apprenticeship places and alternatively the annual number of new training contracts signed as of 30 September as dependent variables. For the independent variables, demographic change is represented by the growth rate in the share of the number of graduates from schools 
of general education. ${ }^{\mathrm{b}}$ Furthermore, we use the growth rate in the proportion of lower secondary school and intermediate secondary school students as proxy variables to distinguish young people without and with the minimum prerequisites, respectively. Of course, this is not an accurate measure, but it appears suitable for making assertions about trends as intermediate secondary school graduates are seen different as lower secondary school graduates in regard to their learning abilities (Dobischat et al. 2012, p. 37).

In addition, economic variables are considered as independent variables. Here, a large number of variables have to be considered. Due to the limited time series points and the correlation among many economic variables, a selection of variables must be made. It is therefore advisable to look for corresponding latent variables that bring forth the development of several time series (see Kau and Lösch 2005, p. 143). We conducted a factor analysis in an attempt to reduce the dimensionality of the time series analysis by combining 9 variables to 2 factors associated with economic development in the period 1970-2011.

Thus, the standardised rates of change in the unemployment rate, employed persons and reported vacancies are merged into a factor called LABOUR MARKET. This factor ought to indicate the demand for workers by the enterprises, which also can indicate the extent to which skilled and other workers are available as alternatives to trainees.

The standardised rates of change in the nominal gross value added, nominal gross domestic product (GDP), gross wages and salaries, capital stock (gross fixed assets), real GDP per employed person and compensation per employee (domestic) are bundled into a factor called GROWTH. This factor expresses the extent to which the national economy has prospered at a given time; thus, the factor also indicates the available financial resources of the national economy. The two factors comprise $88 \%$ of the variance of the 9 variables. The Kaiser-Meyer-Olkin criterion is 0.66 . The results of the factor matrix after orthogonal rotation are shown in Table 1, and the change in the two factors over time is shown in Figure 2.

To control for the cost and benefits of apprentices (c.f. Schönfeld et al. 2010), we also include standardised growth rates of the bargaining apprenticeship pay (Beicht 2011).

Table 1 Results of the explorative factor analysis after orthogonal rotation

\begin{tabular}{|c|c|c|c|}
\hline \multirow[t]{2}{*}{ Variables (standardized rates of change) } & \multicolumn{2}{|c|}{ Factors } & \multirow[t]{2}{*}{ Communality } \\
\hline & GROWTH & LABOUR MARKET & \\
\hline Unemployment rate $^{a)}$ & 0.141 & -0.787 & 0.640 \\
\hline Employed persons ${ }^{\mathrm{a})}$ & 0.112 & 0.833 & 0.706 \\
\hline Reported vacancies ${ }^{a)}$ & -0.021 & 0.871 & 0.759 \\
\hline Gross value added, nominal $^{\text {b) }}$ & 0.958 & 0.152 & 0.941 \\
\hline Gross domestic product, nominab) ${ }^{\mathrm{b})}$ & 0.979 & 0.163 & 0.986 \\
\hline Gross wages and salaries, domestic ${ }^{\mathrm{b})}$ & 0.924 & 0.075 & 0.859 \\
\hline $\begin{array}{l}\text { Capital stock (gross fixed assets) } \\
\text { b) }\end{array}$ & 0.957 & -0.162 & 0.941 \\
\hline Real gross domestic product per employed person ${ }^{\text {b) }}$ & 0.814 & -0.268 & 0.734 \\
\hline Employee compensation per employee (domestic) ${ }^{\text {b) }}$ & 0.936 & -0.215 & 0.922 \\
\hline Proportion of variance explained by factor & 0.59 & 0.29 & \\
\hline Cumulative explained variance of factors & 0.59 & 0.88 & \\
\hline
\end{tabular}

Period: 1970-2011; own calculations based on:

a) Labour market statistics of the Federal Employment Agency.

b) State accounts of the Länder. 


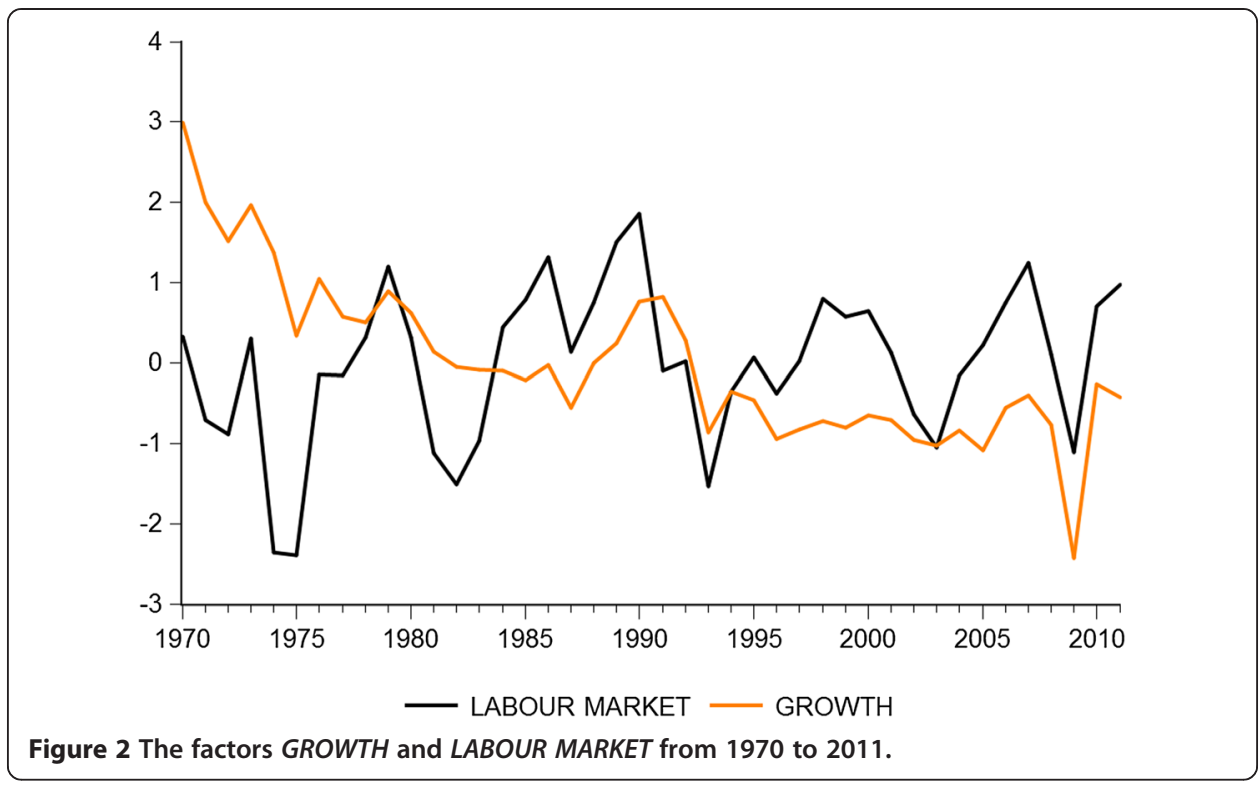

Finally, we conduct a time series analysis (OLS regressions) ${ }^{\mathrm{c}}$ on the rates of change in the number of supplied apprenticeship places (and new training contracts respectively) as of 30 September of each year during 1970-2011 to verify the initial reflections formulated in equation 1. In addition to the results listed, models with lag times between independent and dependent variables were also computed. Those estimates, however, are all less significant than the estimates for the variables without lag times. As a QuandtAndrews breakpoint test ${ }^{\mathrm{d}}$ suggests a structural break in the time series starting at 1991, each of the explanatory variables is multiplied by a dummy variable for the years 19701990 (PRE-UNIFICATION) and a dummy variable for the period 1991-2011 (POSTUNIFICATION). The purpose of this analysis is to identify the effects of each of the explanatory variables before and after German reunification. The data from before 1990 refer to the former federal territory; after reunification, the West German numbers without Berlin are used in the models. We thus have 21 data points for analysis before and 21 points after the structural break in the year 1991. The uncertainties resulting from the small number of cases are thus comparable for the two periods. To ensure reasonable comparisons of the different variables that influence the dependent variable, both the dependent variables and the independent variables are standardised and are all measured in growth rates.

\section{Results of the time series analyses}

The results of the time series analyses are shown in Table 2. The dependent variable in model (I) is the standardised growth rate of the supplied apprenticeship places, the dependent variable in the models (II) to (IV) is the newly signed contracts. Model II, III and IV differ in the operationalization of the demographic influence.

Regarding the variable GROWTH, it is striking that there are no (positive) effects in the pre-unification period but strong positive effects in the post-unification period in all models. There is however no effect of the LABOUR MARKET in every period for every model except for the post-unification period in model III.

Looking on the supply of apprenticeship contracts as the dependent variable (model I), we can see that we have a positive demographic effect in the pre-unification period 


\section{Table 2 Results of the time series analyses, 1970-2011}

Supplied apprentice-ship New contracts ${ }^{\text {a) }} \quad$ New contracts ${ }^{\text {a) }} \quad$ New contracts places $^{\text {a) }}(1970-2011)$

$(1970-201$

$(1970-2011) \quad(1970-2011)$

(I)

GROWTH*PRE-UNIFICATION (1970-1990)

$-0.47^{*}(0.24)$

GROWTH*POST-UNIFICATION (1991-2011)

$1.07 * *(0.44)$

(III)

(IV)

LABOUR MARKET*PRE-UNIFICATION (1970-1990)

$0.31(0.18)$

LABOUR MARKET*POST-UNIFICATION (1991-2011)

$0.43(0.36)$

$-0.08(0.19)$

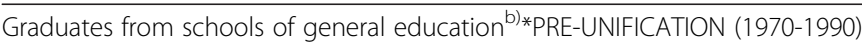

$0.62^{* * *}(0.19)$

$0.04(0.13)$

$0.68^{* *}(0.33)$

$1.01^{* * *}(0.3)$

Graduates from schools of general education ${ }^{\text {b) }}$ POST-UNIFICATION (1991-2011)

$0.71(0.56)$

$0.8^{* * *}(0.13)$

$0.46 *(0.26)$

$0.04(0.12)$

Share of lower secondary school graduates in the total number of graduates)*PRE-UNIFICATION (1970-1990)

$0.3(0.2)$

$0.99^{* *}(0.39)$

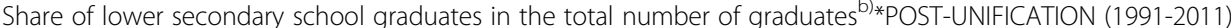

$-0.41^{*}(0.22)$

$0.36^{* *}(0.14)$

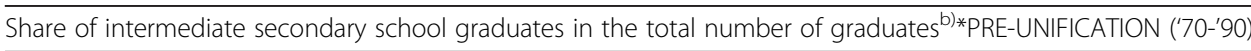

$0.06(0.16)$

$-0.38^{* *}(0.15)$

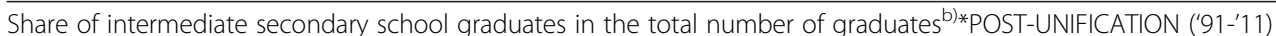

$0.61(0.41)$

$0.74^{* *}(0.28)$

er secondary school graduates in the total number of graduates ${ }^{b) * P R E-U N I F I C A T I O N ~(1970-1990) ~}$

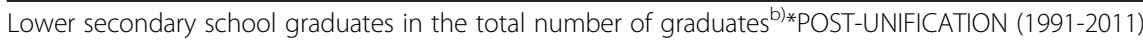

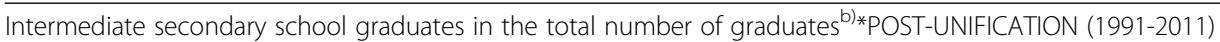

Trend variable

R-squared

Adjusted R-squared

Durbin-Watson statistic

\section{$\mathrm{N}$}

\begin{tabular}{cccc}
$0.02^{* *}(0.01)$ & $0.01^{* * *}(0)$ & $0.01(0.01)$ & $0.01^{* * *}(0)$ \\
\hline 0.57 & 0.76 & 0.66 & 0.80 \\
\hline 0.41 & 0.67 & 0.59 & 0.73 \\
1.67 & 1.91 & 1.43 & 2.13 \\
\hline 42 & 42 & 42 & 42
\end{tabular}

Standard errors in parentheses; * $p<0.10, * * p<0.05, * * * p<0.01$, all variables in growth rates.

a) Survey of the Federal Institute for Vocational Education and Training (BIBB): Training contracts newly concluded by 30 September.

${ }^{b}$ From schools of general education. Statistical publications of the KMK: Schüler, Klassen, Lehrer und Absolventen der Schulen; various years.

c)Source BIBB: Database apprenticeships pay; values for 1970 to 1976 are estimated. 
and no demographic effect in the post-unification period. The same is the case for model (III), where we do not control for the share/amount of school leavers of lower and intermediate secondary schools.

The results of model (I) and (III) indicate that the demographic effect might be stronger or only existent in the post-unification period (compared to the pre-unification period). However, this effect can be traced back to the share (model II) or the amount (model IV) of intermediate secondary school graduates. Whereas in the post-unification period, the influence of lower secondary school graduates on newly signed apprenticeship contracts has been stronger than for intermediate graduates, this correlation is turned around in the post-unification period. Only an increase in intermediate secondary school graduates leads to a higher number of signed apprenticeship contracts after 1991. An increase in lower secondary school graduates has an even negative influence.

The time series analyses shows that the realisation of new training contracts has been affected by different influences in the time before and after the German reunification. In general, we can conclude that demographic effects have been stronger in the preunification period, whereas economic influences have gained in significance in the post-unification period. Furthermore, it seems that in the post-unification period enterprises showed stronger reaction to the demand for apprenticeship places from persons who meet the minimum requirements (see "Hypotheses and analysis models"). To verify our results and to gain a more direct interpretation of the coefficients then from the factors GROWTH and LABOUR MARKET, we now estimate our model with a panel data set on the level of the German states ("Bundesländer").

\section{Panel-data analyses for 1977-2011}

\section{Data, variables and influencing factors}

Compared to the federal state, data on level of the German Bundesländer is more limited and not available for all variables from 1970 onwards. We therefore have to constrain our data from 1977 to 2011. Furthermore, we do not have full information on all variables considered in the factor analysis (cf. Table 1) on the state level. However, due to a larger database in our time-series cross-section data (35 point in time and 10 cross-section units), ${ }^{\mathrm{e}}$ we are now able to estimate effects of the different independent variables in different time periods.

When constructing a panel on basis of regional data, one has to be aware that the interesting variables between the regions may not be independent from each other; e.g. the supply of apprenticeship places in region A may not only depend on the growth rate of school graduates in region A but also on school graduates in the neighbouring region $\mathrm{B}$. However, regional dependencies also depend on the size and characteristics of the region. The state level, which we choose for our analyses, is already a comprised regional area, so that geographical mobility of apprentices between the West German Bundesländer is rather restricted except for the city states Bremen and Hamburg and their surrounding states Lower Saxony and Schleswig-Holstein (c.f. Bogai et al. 2008). To consider the dependence of these four mentioned states in the north, we cluster them as one region. For the same reason, we also cluster the smaller neighbouring states in the south west (Hesse, Rhineland-Palatinate and Saarland). In our panel analyses, we then consider those regional dependencies by estimating cluster-robust standard errors. ${ }^{\mathrm{f}}$ 
To visualise the different effects of the independent variables in the different time periods, we estimate a fixed effects panel regression ${ }^{\mathrm{g}}$ for the first 15 time points (e.g. 1977 to 1990) and then we repeat the estimation for the next 15 time points (e.g. 1978 to 1991) and so on. Then we compare the effects of the different 22 rolling fixed effects panel regressions (from 1977 to 1990 until 1997 to 2011). Each regression is therefore based on 15 time points in 10 cross sections. For straightforward interpretation, we take the logarithm of all variables so that all effects can be interpreted as elasticities. As independent variables we use the unemployment rate, the gross domestic product, the bargaining apprenticeship pay ${ }^{\mathrm{h}}$, the share of lower secondary and intermediate secondary school graduates and graduates from schools of general education.

\section{Results of the panel data analyses}

The effects (elasticities) of the independent variables on the supplied apprenticeship places and the $R^{2}$ (within) of the 22 fixed effects panel regressions are shown in Figure 3. As the results for the new apprenticeship contracts are similar, those are shown in Figure 4. For each time period, we display the coefficient and the corresponding 95\%-confidence interval. In the case that the confidence interval (light blue) is not overlapping the red line, which marks an effect of the size zero, the effect of the independent variable can be considered as significantly different from zero.

The results of the panel data analyses in Figure 3 are not totally congruent to the results of the time series analyses in Table 2 but show strong similarity. In the 1980s, the supply of new apprenticeship contracts has been strongly influenced by demographic factors like the

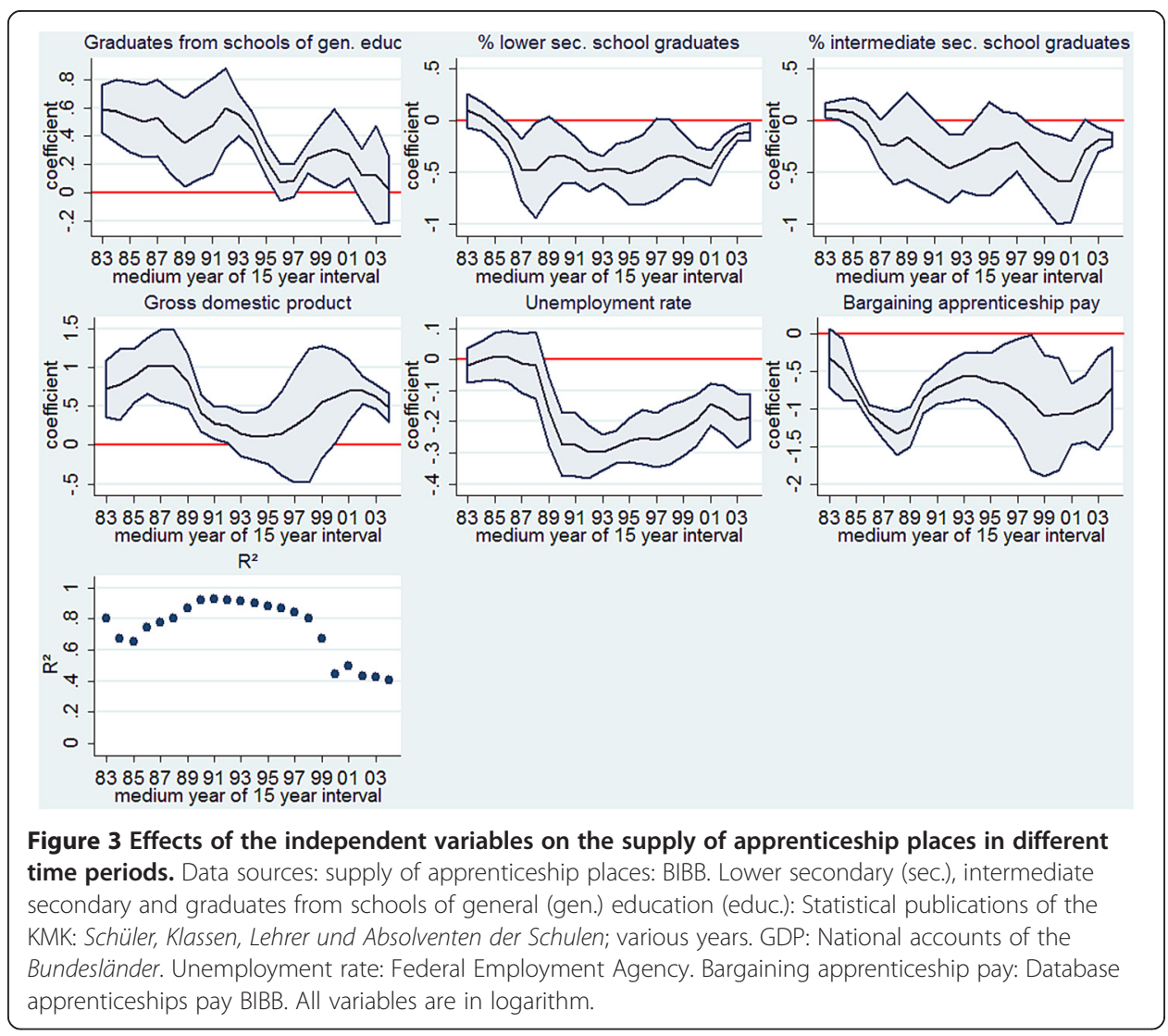




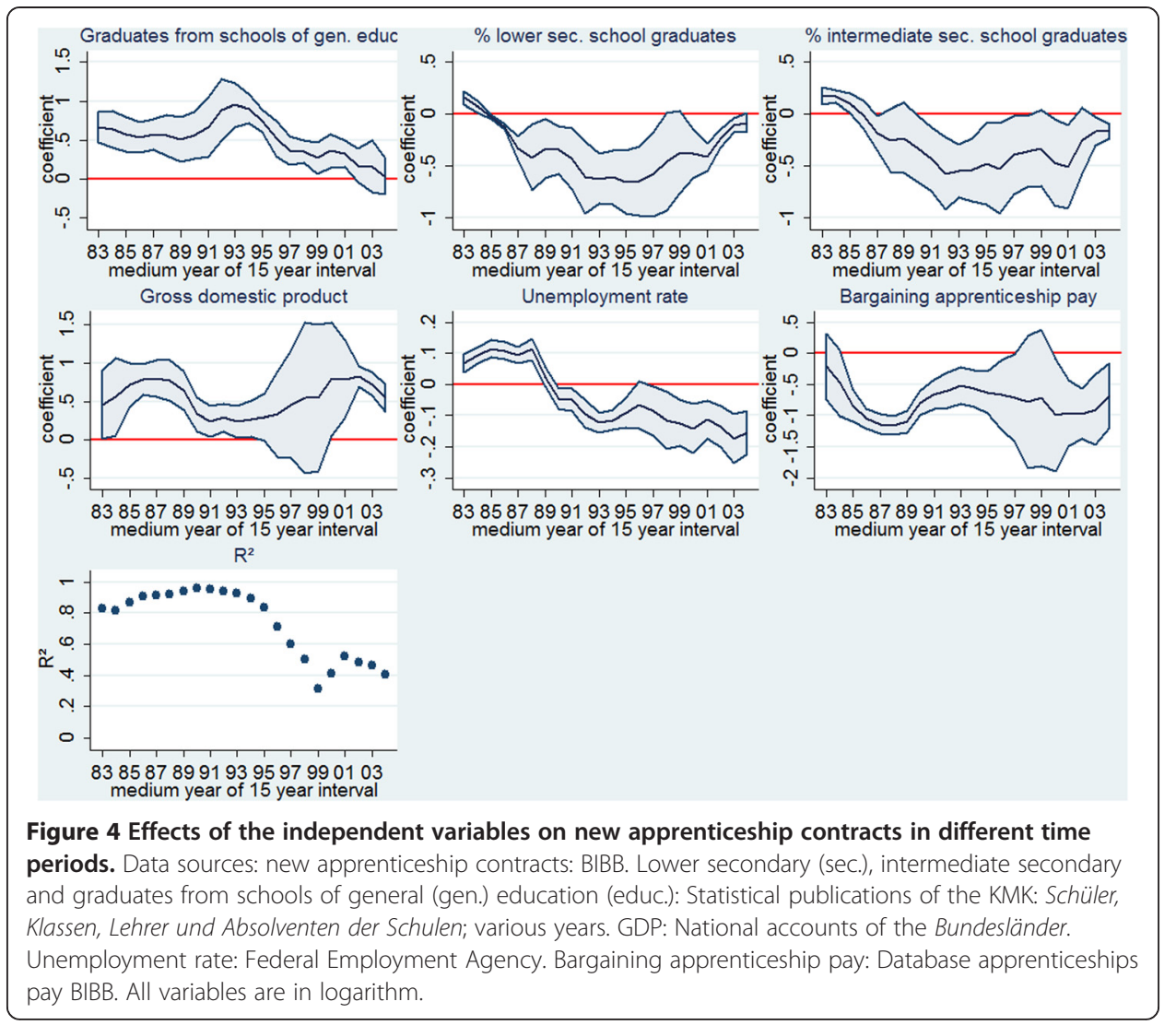

amount of graduates from schools of general education (c.f. Figure 4). A one percent increase of graduates led to an increase of supplied apprenticeship contracts of round about 0.6 percent. Although the positive effect of school graduates persists until the beginning of the millennium, we also see that the share of lower secondary school graduates with the beginning of the mid-1980s and the share of intermediate secondary school graduates with the beginning of the 1990s had a negative impact on the supplied apprenticeship places. ${ }^{\mathrm{i}}$

Except for the 1990s, the GDP has a significant positive effect. This effect has been stronger in size in the 1980s then in years 2000. However, the unemployment rate only turns significant with the beginning of the 1990s. In contrast to the time series analysis (Table 2), the bargaining apprenticeship pay also exhibits a negative influence on the supplied apprenticeship places.

\section{Conclusion}

The results of this analysis demonstrate a clear link between the development of demand and supply in VET only before 1990. Before 1990, more exactly until the mid1980s, enterprises reacted to an increasing number of young people looking for training places by offering more training places and also signing more applicants, irrespective of the educational level of the applicants. These empirical findings confirm the view of Busemeyer (2009) that the economy in the observed period reacted positively to political appeals to provide for young people.

Whereas in the time series it appears that, the influence of demography persists after 1990 but is manifested mostly as a redeployment of trainees from lower secondary 
school students to intermediate secondary school students, we see an overall declining influence of school graduates in the panel analysis (Figure 2). All in all, both methods of data analysis show stronger effects of demography on supply of training places before 1990. Furthermore, our results show that economic factors, as for example the general growth of the economy, the unemployment rate or the apprenticeship pay play an important and increasing role for the supply of apprenticeship places. Fundamental changes in the basic economic conditions in Germany since reunification can explain these patterns. The key concepts to note are globalisation and the increased pressure of international competition. The economic system of the Federal Republic before the unification, with its special form of co-operation between government and business, and the understanding between employers and trade unions, for which the term "Rhein capitalism" was coined, begins to crumble at the end of the 1980s. The old economic system gradually shifts towards a more market-liberal economy, and the dual system of VET is motivated to a greater extent by economic factors. It will be interesting to see, if demography will regain an influence on the supply considering that the demand for apprenticeship places declines due to demographic change.

Regarding policy, these findings suggest that policy makers have an extremely limited ability to influence the number of training places offered by companies through appeals to the community spirit and the social responsibility of enterprises, in contrast to prior times. Strategies of gaining additional training places therefore should be geared towards the economic interests of enterprises. Policy makers should emphasise the economic advantages of training offers and/or the disadvantages of not providing training to companies.

\section{Endnotes}

${ }^{a}$ Of course it has to be considered that school graduates also have alternatives to VET like high school or university enrolment (Mühlemann et al. 2009), but it must also be considered that there is still a high number of applicants of the former years who apply for apprenticeships (Kau and Lösch 2005, Ulrich et al. 2011).

${ }^{b}$ Alternative estimation models have incorporated the rates of change in the absolute numbers of lower secondary and intermediate secondary school students. The results were nearly identical to those obtained when the change in proportions was considered. The number of applicants carried over from previous years is not considered, since the appropriate time series is available only from 1985 onwards. The attempt to approximate the number of applicants from previous years based on the number of school graduates from previous years turned out, in later estimates, to not be fruitful.

${ }^{c}$ All variables are standardised rates of change. The augmented Dickey-Fuller unit root test confirmed that the variables used in the model are stationary.

${ }^{\mathrm{d}}$ A structural break in the year 1991 is also confirmed by a Chow breakpoint test.

${ }^{\mathrm{e}}$ Like in the time series analyses, we excluded Berlin.

${ }^{\mathrm{f}}$ Due to their population size and the rather centred placement of their city areas, North Rhine-Westphalia, Baden-Württemberg and Bavaria are each treated as a single region. Our breakdown of regional clusters therefore corresponds with the Nielsen areas of the Nielsen market research organisation. 
${ }^{\text {g}}$ The Hausman test (Hausman 1978) shows that the random effects model cannot be preferred in all time periods over the fixed effects model. We therefore decide to estimate fixed effects models for every time period to ensure consistent estimates.

${ }^{h}$ The bargaining apprenticeship pay is not available on the state level. Therefore, we used federal state information for every state.

${ }^{\mathrm{i}}$ Positive reactions from enterprises on graduates from schools of general can therefore either be explained by graduates without certificate or the share of graduates with high-school degree (Abitur). Including the latter in the estimation, we see that the negative effect of lower and medium secondary school graduates turns insignificant until the beginning of the years 2000. The significant negative effect of those two groups is later on accompanied with a positive effect of high-school graduates on the supply of apprenticeship places.

\begin{abstract}
Abbreviations
BIBB: Federal Institute for Vocational Education and Training; c.p.: Ceteris paribus; DM: Demand of young people who meet the minimum requirements; DN: Demand of young people who do not meet the minimum requirements; GDP: Gross domestic product; KMK: "Kultusministerkonferenz" standing conference of the ministers of education and cultural affairs of the Länder in the federal republic of Germany; S: Supplied training places; VET: Vocational education and training; Z: Other influencing factors.
\end{abstract}

Competing interests

The authors declare that they have no competing interests.

\title{
Authors' contributions
}

GW developed the concept of the study and is therefore mainly responsible for the background section and the analysis model. TM collected the data and calculated the empirical models. Both authors are responsible for the interpretation of the results and the resulting conclusions. Both authors read and approved the final manuscript.

\section{Acknowledgements}

We thank the anonymous referees, who provided valuable suggestions that improved the paper greatly.

\section{Author details}

'Division "Qualifications, Occupational Integration and Employment", Federal Institute for Vocational Education and Training, Robert-Schuman-Platz 3, 53175 Bonn, Germany. ${ }^{2}$ Head of Department "Sociology and Economics of Vocational Education and Training", Federal Institute for Vocational Education and Training, Robert-Schuman-Platz 3 , 53175 Bonn, Germany.

Received: 18 December 2013 Accepted: 14 February 2014

Published online: 15 May 2014

\section{References}

Baethge M, Solga H, Wieck M (eds) (2007) Netzwerk Bildung. Berufsbildung im Umbruch. Signale eines überfälligen Aufbruchs. Friedrich-Ebert-Stiftung, Bonn

Becker GS (1995) Human capital: a theoretical and empirical analysis, with special reference to education (3. ed., [reprint]). The University of Chicago Press, Chicago

Beicht U (2011) Langzeitentwicklung der tariflichen Ausbildungsvergütung in Deutschland. Wissenschaftliche Diskussionspapiere, Heft 123. Bundesinstitut für Berufsbildung, Bonn, p 65

Bogai D, Seibert H, Wiethölter D (2008) Die Suche nach Lehrstellen macht junge Menschen mobil: Duale Ausbildung in Deutschland. IAB-Kurzbericht 9/2008, Nürnberg

Brunello G (2009) The effect of economic downturns on apprenticeships and initial workplace training: a review of the evidence. Empirical Research in Vocational Education and Training 1(2):145-171

Bundesinstitut für Berufsbildung (2011) Datenreport zum Berufsbildungsbericht 2011. Bonn, Bonn

Busemeyer MR (2009) Wandel trotz Reformstau: Die Politik der beruflichen Bildung seit 1970. Campus Verlag, Frankfurt, Main

Dobischat R, Kühnlein G, Schurgatz R (2012) Ausbildungsreife - ein umstrittener Begriff beim Übergang Jugendlicher in eine Berufsbildung, Arbeitspapiere 189. Hans-Böckler-Stiftung, Düsseldorf

Hausman JA (1978) Specification tests in econometrics. Econometrica 46(6):1251-1271

Kau W, Lösch M (2005) Ökonometrisches Prognose- und Simulationsmodell des Ausbildungssystems (PROSIMA). In: Bundesinstitut für Berufsbildung. Der Ausbildungsmarkt und seine Einflussfaktoren, Bonn, pp 133-146

Kau W, Lösch M, Ulrich JG (2010) Vorausschätzung des Ausbildungsplatzangebots und Ausbildungsplatznachfrage für 2011. In: Bundesinstitut für Berufsbildung. Datenreport zum Berufsbildungsbericht 2010, Bonn, pp 64-76

Lindley RM (1975) Demand for apprentice recruits by the engineering industry: 1951-1971. Scottish Journal of Political Economy 22(1):1-24

Merrilees WJ (1983) Alternative models of apprenticeship recruitment: with special reference to the British engineering industry. Appl Econ 15(1):1-21 
Mühlemann S, Wolter SC, Wüest A (2009) Apprenticeship training and the business cycle. Empirical Research in Vocational Education and Training 1(2):173-186

Schönfeld G, Wenzelmann F, Dionisius R, Pfeifer H, Walden G (2010) Kosten und Nutzen der dualen Ausbildung aus Sicht der Betriebe: Ergebnisse der vierten BIBB-Kosten-Nutzen-Erhebung. Berichte zur beruflichen Bildung, Bertelsmann, Bielefeld

Troltsch K, Walden G (2007) Beschäftigungssystem dominiert zunehmend Ausbildungsstellenmarkt: Zur Responsivität des dualen Ausbildungssystems. Berufsbildung in Wissenschaft und Praxis 36(4):5-9

Troltsch K, Walden G (2010) Beschäftigungsentwicklung und Dynamik des betrieblichen Ausbildungsangebotes: Eine Analyse für den Zeitraum 1999 bis 2008. Zeitschrift für Arbeitsmarktforschung 43(2):107-124

Ulrich JG, Flemming S, Granath R (2011) Ausbildungsmarktbilanz 2010. In: Bundesinstitut für Berufsbildung. Datenreport zum Berufsbildungsbericht 2011, Bonn, pp 11-28

Walden G, Troltsch K (2011) Apprenticeship training in Germany - still a future-oriented model for recruiting skilled workers? Journal of Vocational Education and Training 63(3):305-322

Wolter SC, Ryan P (2011) Apprenticeship. In: Hanushek EA, Machin S, Woessmann L (eds) Handbook of the economics of education, vol 26. North-Holland, Amsterdam/Heidelberg, pp 521-576

doi:10.1186/s40461-014-0004-2

Cite this article as: Maier and Walden: The influence of demographic factors on the supply of company training places in Germany. Empirical Research in Vocational Education and Training 2014 6:4.

Submit your manuscript to a SpringerOpen ${ }^{\circ}$ journal and benefit from:

- Convenient online submission

Rigorous peer review

- Immediate publication on acceptance

- Open access: articles freely available online

- High visibility within the field

Retaining the copyright to your article

Submit your next manuscript at $\gg$ springeropen.com 